\title{
Rumen degradation kinetics of coffee hulls treated with calcium oxide under aerobic or anaerobic conditions
}

\author{
Cinética de degradación ruminal de la cascarilla de café tratada con óxido de calcio en condiciones de \\ aerobiosis o anaerobiosis
}

\section{Cinética de degradação ruminal da casca de café tratada com óxido de cálcio em condição de aerobiose ou anaerobiose}

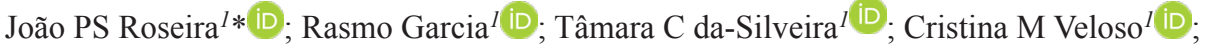 \\ Thiago C da-Silva² ${ }^{(D}$; Leandro D da-Silva ${ }^{l}$ (D); Everton T Ribeiro ${ }^{l}$ (D).
}

${ }^{1}$ Departamento de Zootecnia, Universidade Federal de Viçosa, UFV, Viçosa-MG, Brasil.
${ }^{2}$ Departamento de Zootecnia, Universidade Federal Rural da Amazônia, UFRA, Belém-PA, Brasil.

To cite this article:

Roseira JPS, Garcia R, da-Silveira TC, Veloso CM, da-Silva TC, da-Silva LD, Ribeiro ET. Rumen degradation kinetics of coffee hulls treated with calcium oxide under aerobic or anaerobic conditions. Rev Colomb Cienc Pecu 2021; 34(1): 51-62. DOI: https://doi.org/10.17533/udea.rccp.v34n1a05

\begin{abstract}
Background: Coffee hulls obtained from dry processing, have the potential to be used in ruminant diets. Objective: To evaluate the chemical composition and in situ degradability of dry matter (DM) and neutral detergent fiber (NDF) of coffee hulls treated with calcium oxide $(\mathrm{CaO})$ in different environmental conditions (EC). Methods: Coffee hulls were subjected to treatments distributed in a $2 \times 2$ factorial arrangement, consisting of two levels of $\mathrm{CaO}$ ( 0 and $5 \%$, on a DM basis) and two environmental conditions (aerobiosis and anaerobiosis) in a completely randomized design with four replicates, totaling sixteen experimental units. Five-gram samples were incubated in the rumen of two male cattle for 0, 3, 6, 9, 12, 24, 48, 72, 96, and 120 h. Results: Regarding dry matter degradation kinetic parameters, except for fraction $b$, the potential and effective degradability was affected $(\mathrm{p}<0.05)$ by a $\mathrm{CaO} \times \mathrm{EC}$ interaction. As for estimated fiber degradation parameters, the potentially degradable fraction $\mathrm{b}$ was affected $(\mathrm{p}<0.05)$ by $\mathrm{CaO}$ and $\mathrm{EC}$. Treatment with $\mathrm{CaO}$ increased fraction $\mathrm{b}$ in 4.08 percentage points. Conclusions: The use of $\mathrm{CaO}$ in the treatment of coffee hulls increases the effective and potential degradability of DM and reduces the undegradable fiber fraction. Anaerobic condition is the best environment for the treatment of coffee hulls with $\mathrm{CaO}$.
\end{abstract}

Keywords: alternative feedstuff; calcium oxide; coffee hulls; coffee byproducts; feed ingredient; fiber; fiber degradation; in situ degradability; nutrient degradability; ruminant.

Received: September 19, 2018; accepted: June 11, 2020

*Corresponding autor. Av Peter Henry Rolfs, s/n - Campus Universitário, Cep: 36570-900. Bairro: Centro, Viçosa-MG, Brazil. E-mail: jpr-santos@hotmail.com 


\section{Resumen}

Antecedentes: la cáscara de café obtenida por procesamiento en seco presenta potencial de uso en la alimentación de rumiantes. Objetivo: Evaluar la composición química, la degradabilidad in situ de la materia seca (DM) y de la fibra detergente neutra (NDF) de la cascara de café tratada con óxido de calcio $(\mathrm{CaO})$ en diferentes condiciones ambientales (EC). Métodos: la cáscara de café fue sometida a tratamientos distribuidos en un diseño factorial 2 x 2, dos dosis de CaO ( 0 a $5 \%$ en base seca), y dos condiciones ambientales (aeróbica y anaeróbica) en un diseño completamente al azar con cuatro repeticiones, totalizando dieciséis unidades experimentales. Las muestras de cinco gramos se incubaron en el rumen de dos bovinos machos durante 0, 3, 6, 9, 12, 24, 48, 72, 96 y 120 horas. Resultados: para los parámetros cinéticos de degradación de la DM, a excepción de la fracción $b$, la degradabilidad potencial y efectiva fueron afectadas $(\mathrm{p}<0,05)$ por la interacción $\mathrm{CaO} \times \mathrm{EC}$. En cuanto a los parámetros estimados de la degradación de la fibra, la fracción potencialmente degradable b presentó efecto $(\mathrm{p}<0,05)$ para CaO y EC. El tratamiento con $\mathrm{CaO}$ promovió un aumento de la fracción b en 4,08 puntos porcentuales. Conclusión: la utilización del $\mathrm{CaO}$ para el tratamiento de la cáscara de café aumenta la degradabilidad efectiva y potencial de la DM y reducción de la fracción no degradable de la fibra. La condición de anaerobiosis se constituye en el mejor ambiente para el tratamiento de la cascara de café con $\mathrm{CaO}$.

Palabras clave: alimento alternativo; cáscara de café; degradabilidad de nutrientes; degradabilidad in situ; degradación de la fibra; fibra; ingrediente alimenticio; óxido de calcio; subproductos del café; rumiantes.

\section{Resumo}

Antecedentes: cascas de café obtidas pelo processamento a seco têm potencial de serem usadas na alimentação de ruminantes. Objetivo: avaliar a composição química, a degradabilidade in situ da matéria seca (DM) e da fibra em detergente neutro (NDF) da casca de café tratada com óxido de cálcio $(\mathrm{CaO})$ em diferentes condições de ambiente (EC). Métodos: a casca de café foi submetida aos tratamentos, distribuídos em esquema fatorial $2 \times 2$, sendo duas doses de CaO ( 0 e $5 \%$ base da matéria seca) e duas condições de ambiente (aeróbico e anaeróbico), em delineamento inteiramente casualizado, com quatro repetições, totalizando dezesseis unidades experimentais. Amostras de cinco gramas foram incubadas no rúmen de dois bovinos machos, nos tempos 0, 3, 6, 9, 12, 24, 48, 72, 96 e 120 horas. Resultados: para os parâmetros cinéticos de degradação da DM, à exceção da fração $b$, a degradabilidade potencial e efetiva foram afetados $(p<0,05)$ pela interação $\mathrm{CaO} \times \mathrm{EC}$. Quanto aos parâmetros estimados da degradação da fibra, a fração potencialmente degradável (b) apresentou efeito $(\mathrm{p}<0,05)$ para CaO e EC. O tratamento com $\mathrm{CaO}$ promoveu aumento da fração b em 4,08 pontos percentuais. Conclusões: a utilização do CaO no tratamento da casca de café promove aumento da degradabilidade efetiva e potencial da DM e redução da fração indegradável da fibra. A condição de anaerobiose constitui-se no melhor ambiente para o tratamento da casca de café com CaO.

Palavras-chave: alimentação alternativa; cascas de café; degradabilidade de nutrientes; degradabilidade in situ; degradação da fibra; fibra; ingrediente alimentar; óxido de cálcio; subprodutos de café; ruminante. 


\section{Introduction}

Coffee farming generates a large amount of waste material, including hulls resulting from the dry processing required to obtain coffee beans. This waste has potential to be included in ruminant diets, as shown in the studies reported by Rocha et al. (2006), and Souza et al. (2006). It is noteworthy that this material is readily available at the processing sites, unlike many agricultural waste materials, which remain in the field, thus increasing collection and transport costs (Figueiredo et al., 2008).

Anti-nutritional factors such as caffeine, polyphenols, and tannins present in coffee hulls may negatively affect the intake of this feedstuff (Vargas et al., 1982). Another limitation for including high levels of this waste in diets is the excessive concentration of cell wall components, mostly cellulose, hemicellulose, and lignin. Valadares Filho et al. (2010) reported 65.53 and $50.11 \%$, neutral (NDF) and acid (ADF) detergent fiber, respectively, on a dry matter (DM) basis.

Several alkalis are used in fibrous roughages to promote partial solubilization of the cell wall components and, consequently, increase nutrient utilization. In this regard, the use of calcium oxide $(\mathrm{CaO})$ stands out as the safest low-cost alkaline treatment compared with other alkalis. Research has shown the effectiveness of $\mathrm{CaO}$ at the level of $50 \mathrm{~g} \mathrm{~kg}^{-1} \mathrm{DM}$ for the treatment of corn and wheat straw in anaerobic environment (Sewell et al., 2009; Russell et al., 2011). The reaction of $\mathrm{CaO}$ with water is exothermal and the heat is retained inside a closed container, which might influence the substrate, improving its nutritional quality.

Despite the available volume of coffee hulls and previous research on its use in fresh form (Rocha et al., 2006; Souza et al., 2006), further research is needed to treat coffee hulls, with $\mathrm{CaO}$. Therefore, the present study aimed to evaluate the chemical composition and rumen degradation kinetics of $\mathrm{DM}$ and NDF of coffee hulls treated with $\mathrm{CaO}$ under aerobic and anaerobic conditions.

\section{Materials and methods}

\section{Ethical considerations}

The experimental procedures were undertaken according to the norms of the Ethics Committee in Livestock Research of the Universidade Federal de Viçosa (UFV-CEUAPUFV, approval no. 58/2014).

\section{Location and treatment of hulls}

The experiment was carried out in Campo Agropecuário and in Laboratório de Forragicultura of Departamento de Zootecnia at Universidade Federal de Viçosa (UFV), Viçosa campus.

Treatments were arranged in a $2 \times 2$ factorial design consisting of two $\mathrm{CaO}$ levels $(0$ and $5 \%$, on a dry matter basis) and two environment conditions (aerobiosis and anaerobiosis), in a completely randomized design with four replicates, totaling sixteen experimental units.

Coffee hulls were obtained after the grain was dry-processed. The material was homogenized, and a sample was collected to estimate DM prior to application of treatments using the Karl Fischer method (Bruttel and Schlink, 2006) in a 870 KF Tritino Plus KF titrator (Metrohm, São Paulo, SP, Brazil).

After assessing for DM content, the moisture of coffee hulls was adjusted to $50 \%$ by adding water (Shreck, 2013). For the $0 \% \mathrm{CaO}$ treatment, $3 \mathrm{~kg}$ of coffee hulls were added to $0.50 \times 0.70$ $\mathrm{m}$ transparent polyethylene bags (Cepel, São Paulo, SP, Brazil). For the $5 \% \mathrm{CaO}$ treatment, powdered $\mathrm{CaO}$ was added to $3 \mathrm{~kg}$ of coffee hulls and the mixture was homogenized. To obtain the aerobic environment, bags were kept opened during the entire experimental period, whereas anaerobiosis was obtained with an Eco vacum 1040 vacuum sealer (Orved, Musil di Piave, VE, Italy). The experimental units were stored in a protected location at room temperature for seven days (Shreck, 2013). 


\section{Microbiological and chemical analysis}

Before the moisture adjustment, a sample of coffee hulls was collected to analyze for chemical composition (following Detmann et al.,2012) and for microbial counts, i.e., molds and yeasts (Table 1).

Table 1. Chemical composition and mold-yeast count of fresh coffee hulls.

\begin{tabular}{lc}
\hline Component & Composition (\%) \\
\hline Dry matter (\%) $^{(\%)}$ & 88.40 \\
Crude protein $^{l}$ & 10.52 \\
Neutral detergent insoluble nitrogen $^{2}$ & 40.50 \\
Acid detergent insoluble nitrogen $^{2}$ & 20.99 \\
Ether extract $^{1}$ & 1.12 \\
NDFap $^{{ }^{*}}$ & 52.47 \\
Indigestible neutral detergent fiber $^{l}$ & 44.31 \\
Acid detergent fiber $^{l}$ & 42.76 \\
Cellulose $^{l}$ & 28.18 \\
Hemicellulose $^{l}$ & 15.78 \\
Lignin $^{l}$ & 14.50 \\
Non-fibrous carbohydrates $^{l}$ & 27.18 \\
Total carbohydrates $^{1}$ & 79.65 \\
Ash $^{l}$ & 8.77 \\
Estimated total digestible nutrients $^{3}$ & 43.45 \\
Mold and yeasts (Log CFU/g) $^{4}$ & 7.26 \\
\hline
\end{tabular}

${ }^{1}$ Percentage of dry matter. ${ }^{2}$ Percentage of total nitrogen. ${ }^{3}$ Estimated according to the NRC (2001). ${ }^{4} \mathrm{CFU}$, colony-forming unit. *neutral detergent fiber corrected for ash and protein.

After seven days, a $25 \mathrm{~g}$ sample of the material was taken to quantify molds and yeasts populations, as described by Silva et al. (1997). The culture of microorganisms was carried out in sterile Petri plate in Potato Dextrose Agar medium (Kasvi, São José dos Pinhais, PR, Brazil) added with $1.5 \%$ tartaric acid $10 \%$, using the Pour-plate technique. Plates showing between 30 and 300 colony-forming units (CFU) were considered suitable for counting, and the results were converted to log base ( $\left.\log _{10} \mathrm{CFU}\right)$. The second sample was weighed and dried in a forced-air oven (Fabbe-Primar, São Paulo, SP, Brazil) at $55^{\circ} \mathrm{C}$ for $72 \mathrm{~h}$. Subsequently, the hulls were ground in a knife mill (Tecnal, Piracicaba, SP, Brazil) through 1- and 2-mm sieve. The concentration of DM, crude protein (CP), neutral detergent fiber corrected for ash and protein (NDFap), cellulose (CEL), hemicellulose (HEM), and lignin (LIG) was analyzed according to Detmann et al. (2012).

Experimental procedures, dry matter and neutral detergent fiber degradability

For the in situ degradability trial, samples of approximately $5.0 \mathrm{~g}$ ( $2 \mathrm{~mm}$ particles) were weighed and stored in previously weighed nylon bags $(17 \times 10 \mathrm{~cm})$ with a pore size of $40 \mu \mathrm{m}$. Four bags from each treatment, per incubation time, were incubated in two rumen-fistulated male cattle $(450 \mathrm{~kg}$ body weight) at the following incubation times: 3 , 6, 9, 12, 24, 48, 72, 96, and $120 \mathrm{~h}$. Bags were placed in reverse order, i.e., from the longest to the shortest incubation time, and removed simultaneously to be washed with the bags corresponding to time zero, which were not incubated. During the experimental period the animals received a diet containing 60\% elephant grass (Pennisetum purpureum), 20\% coffee hulls, and $20 \%$ concentrate, on a DM basis. After removing from the rumen, the bags were washed in running water, dried for $72 \mathrm{~h}$ in a ventilated oven at $55^{\circ} \mathrm{C}$, and then weighed again. Subsequently, the bags were opened, and the residue was analyzed for the DM and NDF concentration, as described by Detmann et al. (2012).

The following equation, proposed by Ørskov and McDonald (1979), was used for the estimation of DM degradation kinetic parameters: $\mathrm{Dt}=\mathrm{a}+\mathrm{b} \times\left(1-\mathrm{e}^{-\mathrm{ct}}\right)$, in which $\mathrm{Dt}$ is the fraction degraded at time $\mathrm{t}(\%)$; $\mathrm{a}$ is the water-soluble fraction $(\%)$; $b$ is the potentially degradable insoluble fraction (\%); c is the degradation rate of fraction $b\left(\mathrm{~h}^{-1}\right)$; and $\mathrm{t}$ is the incubation time $\left(\mathrm{h}^{-1}\right)$. Effective degradability (ED) was calculated through as: $E D=a+(b \times$ $\mathrm{c}) /(\mathrm{c}+\mathrm{k})$, in which $\mathrm{k}$ is the rumen passage rate of the particles, considering rates of 2 and $5 \%$ (Ørskov and McDonald, 1979). 
For NDF degradation, the model proposed by Waldo et al. (1972) was used, according to the formula: $\hat{\mathrm{Y}}=\mathrm{b} \times \mathrm{e}^{(-\mathrm{ct})}+\mathrm{I}$, in which $\hat{\mathrm{Y}}$ is the undegradable residue at time $\mathrm{t}(\%)$; $\mathrm{b}$ is the potentially degradable fraction of the fiber (\%); $\mathrm{c}$ is the degradation rate of $\mathrm{b}\left(\mathrm{h}^{-1}\right)$; $\mathrm{t}$ is the incubation time $\left(\mathrm{h}^{-1}\right)$; and $\mathrm{I}$ is the insoluble, undegradable fraction $(\%)$.

\section{Statistical analysis}

Data were analyzed as a $2 \times 2$ factorial arrangement in a completely randomized design using the MIXED procedure of SAS ${ }^{\circledR}$ software, version 9.3 (SAS Institute, Inc., Cary, NC, USA; 2011). The degradation curve of DM and NDF for each treatment was adjusted by the respective models using the Marquardt Regression procedure to generate the parameter estimates. Homogeneity of variances among treatments was assumed and degrees of freedom were estimated using the Kenward-Roger method. Data were subjected to analysis of variance, and means compared by the F test, with 0.05 as the critical probability level for a type I error.

\section{Results}

All chemical composition variables and mold and yeast counts were affected $(\mathrm{p}<0.05)$ by $\mathrm{CaO} \times \mathrm{EC}($ Table 2$)$. Treated coffee hulls showed higher DM $(p<0.05)$ compared with the untreated ones in both aerobic and anaerobic environments (Table 2), and higher temperatures were recorded in this material after treatment with $\mathrm{CaO}$ (data not shown). Untreated hulls under anaerobic condition showed higher DM than those in the aerobic condition, while $\mathrm{CaO}$ treated hulls did not show differences between the environment conditions for DM concentration. Treating hulls with $\mathrm{CaO}$ promoted a reduction $(p<0.05)$ in CP, NDFap, HEM and LIG fractions and populations of molds and yeasts in both the aerobic and anaerobic conditions (Table 2). Under anaerobic condition, there was a reduction $(p<0.05)$ in CP, NDFap, CEL and LIG contents and populations of molds and yeasts of the untreated and treated hulls when compared with the aerobic environment. Hemicellulose had a greater reduction $(\mathrm{p}<0.05)$ under aerobiosis in both treated and untreated hulls (Table 2).

For DM degradation kinetic parameters, except for fraction $b$, potential degradability (PD) and effective degradability (ED) were affected $(p<0.05)$ by $\mathrm{CaO} \times \mathrm{EC}$ (Table $3)$. Coffee hulls treated with $\mathrm{CaO}$ showed higher $(p<0.05)$ soluble fraction (a) values in comparison with the untreated hulls under both environments (Table 3 ). The environments did not affect $(\mathrm{p}>0.05)$ the potentially degradable fraction $b$, with a mean of $32.35 \%$. The use of $\mathrm{CaO}$ increased $(\mathrm{p}<0.05)$ this fraction in 3.26 percentage points when compared with its absence (Table 3). No difference was observed $(p>0.05)$ between degradation rates (c) of fraction $\mathrm{b}$ with the use of $\mathrm{CaO}$ in both environments compared with untreated hulls. Higher degradation rate $(p<0.05)$ was obtained for untreated hulls in anaerobic than in the aerobic environment, with respective mean values of 0.05 and $0.03 \% / \mathrm{h}$ (Table 3 ). The PD result demonstrated the effectiveness of the alkali used in the treatment of hulls (Table $3)$. The $\mathrm{CaO}$ provided an increase $(\mathrm{p}<0.05)$ in PD compared with the untreated hulls in both environments. Higher PD $(p<0.05)$ was also found for treated hulls under anaerobiosis compared with the aerobic condition, with values of 67.58 and $65.15 \%$, respectively (Table 3).

Figure 1 shows degradation curves adjusted by the model proposed for DM. Higher degradability was seen in hulls treated with $\mathrm{CaO}$ under anaerobiosis. After $72 \mathrm{~h}$ incubation, DM degradability tended to remain constant in all treatments.

No effect $(\mathrm{p}>0.05)$ of $\mathrm{CaO} \times \mathrm{EC}$ was detected on the estimated degradation parameters of NDF. The potentially degradable fraction (b) was affected $(p<0.05)$ by the environment and $\mathrm{CaO}$. The $\mathrm{CaO}$ increased this fraction $(\mathrm{p}<0.05)$ by 4.08 percentage points when compared with the untreated hulls (Table 4). Undegradable fraction I was affected $(\mathrm{p}<0.05)$ 
by the environment and $\mathrm{CaO}$. The $\mathrm{CaO}$ led to a reduction $(p<0.05)$ of this fraction, with values of 66.30 and $61.93 \%$ for the untreated and treated hulls, respectively (Table 4). Hulls under anaerobiosis showed an increase $(p<0.05)$ in fraction $b$ and a reduction $(p<0.05)$ of undegradable fraction I as compared with the aerobic environment (Table 4). No effect was observed $(p>0.05)$ for the use of $\mathrm{CaO}$ or the type of environment on degradation rates of fraction $b$, indicating that neither $\mathrm{CaO}$ nor the environment interferes with that variable (Table 4).

Table 2. Chemical composition of coffee hulls treated or untreated with calcium oxide in aerobic or anaerobic conditions.

\begin{tabular}{|c|c|c|c|c|c|c|c|}
\hline \multirow{2}{*}{$\mathrm{CaO}(\%)$} & \multicolumn{2}{|c|}{ Environment condition (EC) } & \multirow{2}{*}{ Mean } & \multirow{2}{*}{ SEM } & \multicolumn{3}{|c|}{ p-value } \\
\hline & Aerobiosis & Anaerobiosis & & & $\mathrm{CaO}$ & EC & $\mathrm{CaO} \times \mathrm{EC}$ \\
\hline \multicolumn{4}{|c|}{$\mathrm{DM}(\%)$} & 0.568 & $<0.01$ & $<0.01$ & $<0.01$ \\
\hline 0 & $46.40^{\mathrm{Bb}}$ & $47.41^{\mathrm{Ba}}$ & 46.90 & & & & \\
\hline 5 & $50.00^{\mathrm{Aa}}$ & $50.14^{\mathrm{Aa}}$ & 50.07 & & & & \\
\hline Mean & 48.20 & 48.77 & & & & & \\
\hline \multicolumn{4}{|c|}{ Crude protein $(\% \mathrm{DM})$} & 0.262 & $<0.01$ & $<0.01$ & $<0.01$ \\
\hline 0 & $13.90^{\mathrm{Aa}}$ & $11.95^{\mathrm{Ab}}$ & 12.92 & & & & \\
\hline 5 & $12.16^{\mathrm{Ba}}$ & $10.75^{\mathrm{Bb}}$ & 11.45 & & & & \\
\hline Mean & 13.03 & 11.34 & & & & & \\
\hline \multicolumn{4}{|c|}{$\mathrm{NDFap}^{I}(\% \mathrm{DM})$} & 1.018 & $<0.01$ & $<0.01$ & $<0.01$ \\
\hline 0 & $56.42^{\mathrm{Aa}}$ & $51.68^{\mathrm{Ab}}$ & 54.00 & & & & \\
\hline 5 & $48.00^{\mathrm{Ba}}$ & $46.86^{\mathrm{Bb}}$ & 47.44 & & & & \\
\hline Mean & 52.22 & 49.22 & & & & & \\
\hline \multicolumn{4}{|c|}{ Cellulose (\%DM) } & 0.561 & $<0.27$ & $<0.01$ & $<0.01$ \\
\hline 0 & $33.09^{\mathrm{Aa}}$ & $28.81^{\mathrm{Bb}}$ & 30.95 & & & & \\
\hline 5 & $31.58^{\mathrm{Ba}}$ & $29.95^{\mathrm{Ab}}$ & 30.77 & & & & \\
\hline Mean & 32.34 & 29.38 & & & & & \\
\hline \multicolumn{4}{|c|}{ Hemicellulose (\%DM) } & 0.521 & $<0.01$ & $<0.01$ & $<0.01$ \\
\hline 0 & $11.64^{\mathrm{Ab}}$ & $13.27^{\mathrm{Aa}}$ & 12.45 & & & & \\
\hline 5 & $5.68^{\mathrm{Bb}}$ & $9.37^{\mathrm{Ba}}$ & 7.52 & & & & \\
\hline Mean & 8.66 & 11.32 & & & & & \\
\hline \multicolumn{4}{|c|}{ Lignin $(\% \mathrm{DM})$} & 0.540 & $<0.01$ & $<0.01$ & $<0.01$ \\
\hline 0 & $18.58^{\mathrm{Aa}}$ & $14.15^{\mathrm{Ab}}$ & 16.36 & & & & \\
\hline 5 & $15.29^{\mathrm{Ba}}$ & $12.20^{\mathrm{Bb}}$ & 13.74 & & & & \\
\hline \multirow[t]{2}{*}{ Mean } & 16.93 & 13.17 & & & & & \\
\hline & \multicolumn{2}{|c|}{$\begin{array}{c}\text { Molds and yeasts ( } \log \\
\text { CFU/g) }\end{array}$} & & 0.954 & $<0.01$ & $<0.01$ & $<0.01$ \\
\hline 0 & $8.85^{\mathrm{Aa}}$ & $3.04^{\mathrm{Ab}}$ & 5.94 & & & & \\
\hline 5 & $8.48^{\mathrm{Ba}}$ & $\mathrm{ND} * \mathrm{Bb}$ & 4.24 & & & & \\
\hline Mean & 8.66 & 1.52 & & & & & \\
\hline
\end{tabular}

${ }^{l}$ Neutral detergent fiber corrected for ash and protein. ND, not detected (lower value $1 \mathrm{Log}$ CFU/g). Means followed by the same uppercase superscript letters $\left({ }^{A}, \mathrm{~B}\right)$ within columns and lowercase superscript letters ${ }^{(\mathrm{a}, \mathrm{b}}$ ) within rows do not differ $(\mathrm{p}>0.05)$ by the $\mathrm{F}$ test. 
Table 3. Degradation parameters and in situ degradability of dry matter of coffee hulls treated or untreated with calcium oxide in aerobic or anaerobic conditions.

\begin{tabular}{|c|c|c|c|c|c|c|c|}
\hline \multirow{2}{*}{$\mathrm{CaO}(\%)$} & \multicolumn{2}{|c|}{ Environment condition (EC) } & \multirow{2}{*}{ Mean } & \multirow{2}{*}{ SEM } & \multicolumn{3}{|c|}{ p-value } \\
\hline & Aerobiosis & Anaerobiosis & & & $\mathrm{CaO}$ & EC & $\mathrm{CaO} \times \mathrm{EC}$ \\
\hline \multicolumn{4}{|c|}{$\mathrm{a}^{l}(\%)$} & 1.201 & 0.001 & $<0.001$ & 0.0079 \\
\hline 0 & $25.36^{\mathrm{Bb}}$ & $31.40^{\mathrm{Ba}}$ & 28.38 & & & & \\
\hline 5 & $30.69^{\mathrm{Ab}}$ & $34.09^{\mathrm{Aa}}$ & 32.39 & & & & \\
\hline Mean & 28.02 & 32.74 & & & & & \\
\hline \multicolumn{4}{|c|}{$\mathrm{b}^{2}(\%)$} & 0.729 & 0.0155 & 0.7309 & 0.1879 \\
\hline 0 & 29.94 & 31.51 & $30.72^{\mathrm{B}}$ & & & & \\
\hline 5 & 34.46 & 33.49 & $33.98^{\mathrm{A}}$ & & & & \\
\hline Mean & $32.20^{\mathrm{a}}$ & $32.50^{\mathrm{a}}$ & & & & & \\
\hline \multicolumn{4}{|c|}{$\mathrm{c}^{3}(\% / \mathrm{h})$} & 0.002 & 0.7616 & 0.0202 & 0.0421 \\
\hline 0 & $0.03^{\mathrm{Ab}}$ & $0.05^{\mathrm{Aa}}$ & 0.04 & & & & \\
\hline 5 & $0.04^{\mathrm{Aa}}$ & $0.04^{\mathrm{Aa}}$ & 0.04 & & & & \\
\hline Mean & 0.04 & 0.05 & & & & & \\
\hline \multicolumn{4}{|c|}{$\mathrm{PD}^{4}(\%)$} & 1.755 & 0.0003 & 0.0014 & 0.0151 \\
\hline 0 & $55.30^{\mathrm{Bb}}$ & $62.90^{\mathrm{Ba}}$ & 59.10 & & & & \\
\hline 5 & $65.15^{\mathrm{Ab}}$ & $67.58^{\mathrm{Aa}}$ & 66.36 & & & & \\
\hline Mean & 60.23 & 65.24 & & & & & \\
\hline \multicolumn{4}{|c|}{$\mathrm{ED}^{5} 2 \% / \mathrm{h}(\%)$} & 1.842 & $<0.001$ & $<0.001$ & $<0.001$ \\
\hline 0 & $43.42^{\mathrm{Bb}}$ & $53.26^{\mathrm{Ba}}$ & 48.34 & & & & \\
\hline 5 & $53.25^{\mathrm{Ab}}$ & $56.35^{\mathrm{Aa}}$ & 54.80 & & & & \\
\hline Mean & 48.33 & 54.8 & & & & & \\
\hline \multicolumn{4}{|c|}{$\mathrm{ED}^{5} 5 \% / \mathrm{h}(\%)$} & 1.743 & $<0.001$ & $<0.001$ & 0.008 \\
\hline 0 & $36.71^{\mathrm{Bb}}$ & $46.38^{\mathrm{Ba}}$ & 41.54 & & & & \\
\hline 5 & $45.55^{\mathrm{Ab}}$ & $48.90^{\mathrm{Aa}}$ & 47.23 & & & & \\
\hline Mean & 41.13 & 47.64 & & & & & \\
\hline
\end{tabular}

${ }^{1}$ Soluble fraction. ${ }^{2}$ Potentially degradable fraction. ${ }^{3}$ Degradation rate of fraction b. ${ }^{4}$ Potential degradability (fraction a + b). ${ }^{5}$ Effective degradability. Means followed by the same uppercase superscript letters $\left({ }^{A}, \mathrm{~B}\right)$ within columns and lowercase superscript letters $\left({ }^{\mathrm{a}, \mathrm{b}}\right)$ within rows do not differ ( $\mathrm{p}>0.05)$ by the $\mathrm{F}$ test.

Figure 2 shows the degradation curves adjusted by the model proposed for NDF. The treatments with $\mathrm{CaO}$ in anaerobic conditions led to a greater NDF degradation, while untreated hulls under aerobiosis showed the lowest degradability for this component. After $72 \mathrm{~h}$, fiber degradation remained constant in all treatments.

\section{Discussion}

The high DM contents observed in the treated coffee hulls were attributed to the high DM concentration of $\mathrm{CaO}$ (approximately 96\%). Additionally, quicklime reduced water activity in the treated hulls, thus reducing growth of molds and yeasts and nutrient losses (Table 2).

The lowest CP content (10.75\%) was recorded when hulls were treated with $\mathrm{CaO}$ under anaerobiosis, which is close to that observed for fresh hulls before moisture adjustment (Table 1). According to Sampaio et al. (2010), 10\% CP is a level that optimizes the use of energy substrates from roughages and provides conditions for the rumen microorganisms to have full capacity 
to degrade fibrous carbohydrates. Higher CP values observed in the other treatments can be attributed to the contribution of microbial protein present in the material; in this regard, reduced microbial activity (molds and yeasts) was observed in hulls treated under anaerobiosis (Table 2).

Reduction of NDFap, HEM, and LIG when using $\mathrm{CaO}$ was probably due to hydrolytic action ofthealkalion thechemicalbonds betweenfibrous carbohydrates and lignin present in the cell wall. During hydrolysis, lime reacts with water from the residue and the formation of a strong base occurs, calcium hydroxide $\left(\mathrm{Ca}(\mathrm{OH})_{2}\right)$, causing hydrogen bridge bonds to break, resulting in partial solubilization of cell wall constituents. Concentration of CEL was reduced only under anaerobiosis (Table 2). According to Jackson (1977), when treated with alkaline agents, CEL is not dissolved, but expands, reducing the resistance of intermolecular bonds of hydrogen bridges. Jackson (1977) also emphasized that the proportion of CEL in the treated waste is larger than in its untreated version. In the present experiment, this response was observed only under anaerobiosis, in which material showed a CEL content of 29.95 versus $28.81 \%$ for the untreated hulls (Table 2). This finding agrees with Chaudhry (2000), who observed an increase in CEL content of wheat straw treated with $\mathrm{CaO}$ under anaerobiosis of 45.10 and $52.80 \%$ in the treated and untreated straw, respectively.

The reduction of HEM is possibly related to degradation, since aerobiosis favored the growth of molds and yeasts (Table 2). McDonald et al. (1991) stated that the substrate used for respiration depends on the type of microorganisms and that yeasts consume only soluble compounds (sugars and fermentation productions), whereas molds degrade a wide range of nutrients, including structural carbohydrates and lignin.

As for DM degradation parameters, it is evident that the increase of fraction a was due to an action of the alkaline agent through a break of bonds between lignin and cell wall carbohydrates, or even hydrolysis of cell wall polysaccharides, resulting in the release of soluble sugars.

Table 4. Degradation parameters of neutral detergent fiber in coffee hulls treated or untreated with calcium oxide in aerobic or anaerobic conditions.

\begin{tabular}{|c|c|c|c|c|c|c|c|}
\hline \multirow{2}{*}{$\mathrm{CaO}(\%)$} & \multicolumn{2}{|c|}{ Environment condition (EC) } & \multirow{2}{*}{ Mean } & \multirow{2}{*}{ SEM } & \multicolumn{3}{|c|}{ p-value } \\
\hline & Aerobiosis & Anaerobiosis & & & $\mathrm{CaO}$ & EC & $\mathrm{CaO} \times \mathrm{EC}$ \\
\hline \multicolumn{4}{|c|}{$\mathrm{b}^{1}(\%)$} & 1.123 & 0.0320 & 0.0500 & 0.4298 \\
\hline 0 & 31.48 & 35.91 & $33.70^{\mathrm{B}}$ & & & & \\
\hline 5 & 36.68 & 38.89 & $37.78^{\mathrm{A}}$ & & & & \\
\hline Mean & $34.08^{b}$ & $37.40^{\mathrm{a}}$ & & & & & \\
\hline \multicolumn{4}{|c|}{$c^{2}(\%)$} & 0.2693 & 0.081 & 0.2623 & 0.1879 \\
\hline 0 & 0.03 & 0.04 & 0.03 & & & & \\
\hline 5 & 0.04 & 0.04 & 0.04 & & & & \\
\hline Mean & 0.03 & 0.04 & & & & & \\
\hline \multicolumn{4}{|c|}{$I^{3}(\%)$} & 1.113 & 0.0137 & 0.0428 & 0.2567 \\
\hline 0 & 68.51 & 64.09 & $66.30^{\mathrm{A}}$ & & & & \\
\hline 5 & 62.77 & 61.10 & $61.93^{\mathrm{B}}$ & & & & \\
\hline Mean & $65.64^{\mathrm{a}}$ & $62.59 b$ & & & & & \\
\hline
\end{tabular}

${ }^{l}$ Potentially degradable fraction. ${ }^{2}$ Degradation rate of fraction $b .{ }^{3}$ Undegradable fraction. Means followed by the same uppercase superscript letters $(\mathrm{A}, \mathrm{B})$ within columns and lowercase superscript letters $\left({ }^{\mathrm{a}}{ }^{\mathrm{b}}\right)$ within rows do not differ $(\mathrm{p}>0.05)$ by the $\mathrm{F}$ test. 


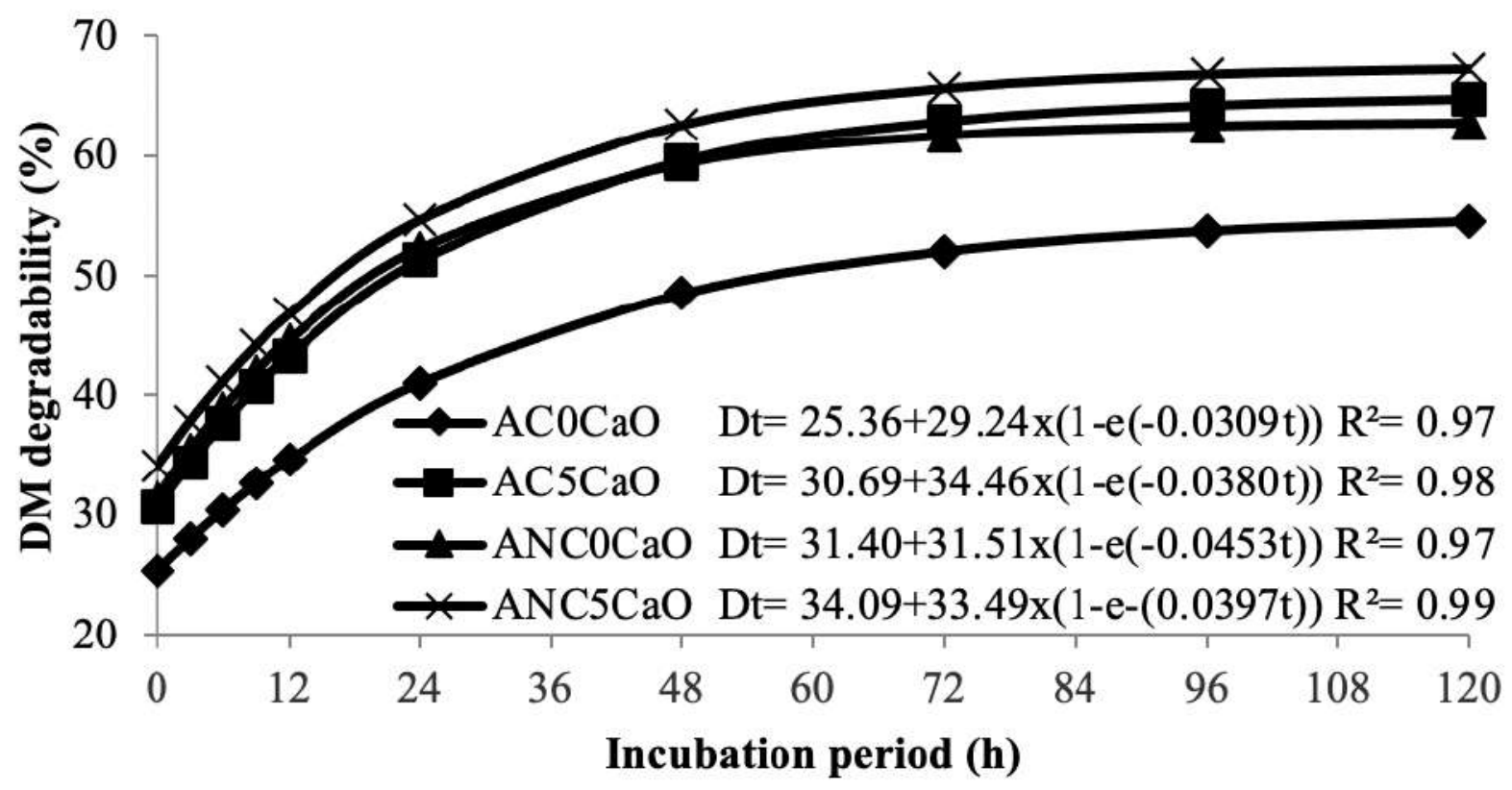

Figure 1. Curves and equations of dry matter degradability in coffee hulls treated or untreated with calcium oxide under aerobic or anaerobic conditions. $\mathrm{AC} 0 \mathrm{CaO}$ : aerobic condition, $0 \% \mathrm{CaO}$; $\mathrm{AC} 5 \mathrm{CaO}$ : aerobic condition, 5\% $\mathrm{CaO}$; $\mathrm{ANC} 0 \mathrm{CaO}$ : anaerobic condition, $0 \% \mathrm{CaO}$; ANC5CaO: anaerobic condition, 5\% $\mathrm{CaO}$.

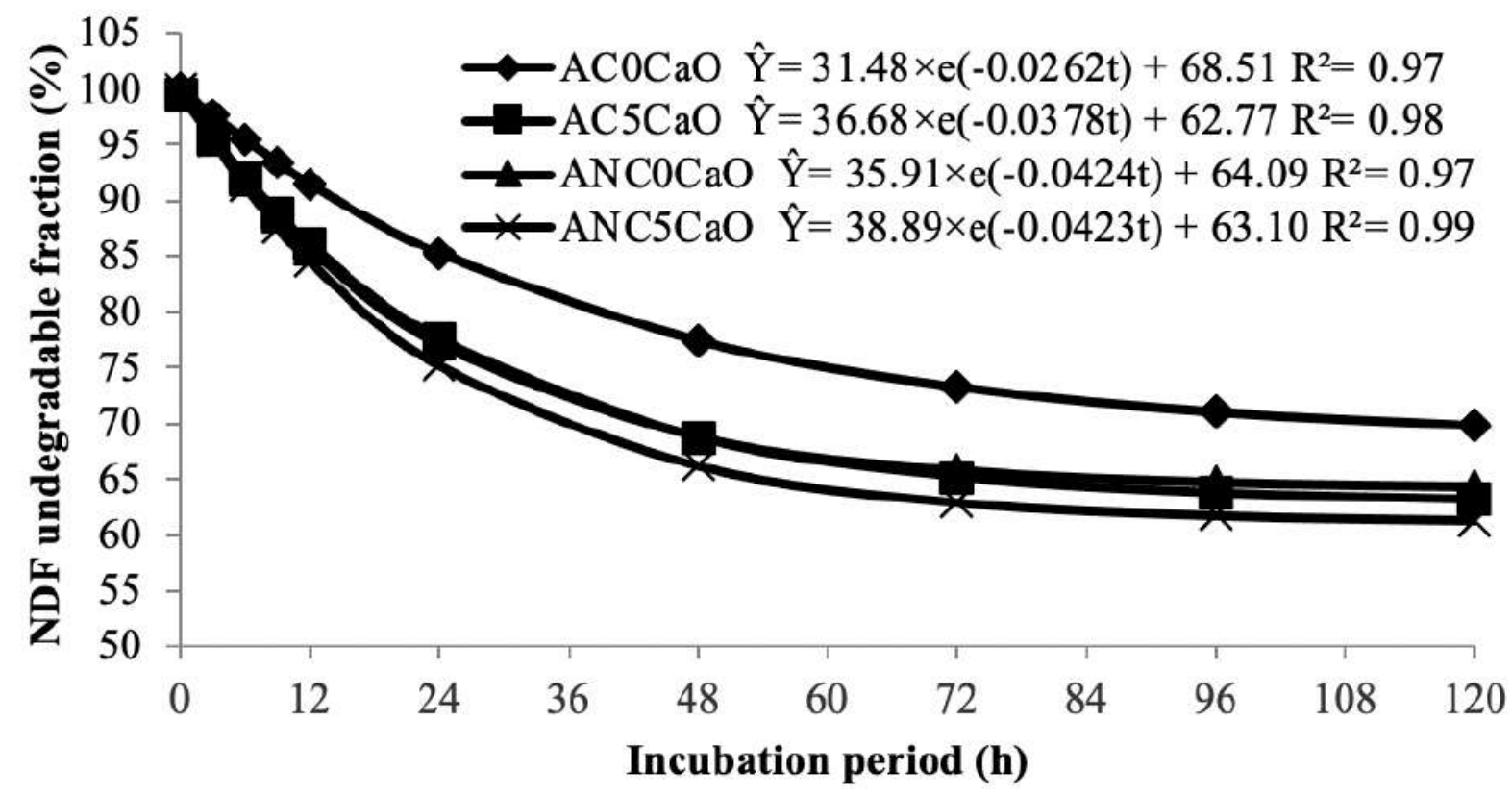

Figure 2. Curves and equations for the undegradable fraction of neutral detergent fiber in coffee hulls treated or untreated with calcium oxide under aerobic or anaerobic conditions. $\mathrm{AC} 0 \mathrm{CaO}$ : aerobic condition, $0 \% \mathrm{CaO}$; $\mathrm{AC} 5 \mathrm{CaO}$ : aerobic condition, $5 \%$ $\mathrm{CaO}$; $\mathrm{ANC} 0 \mathrm{CaO}$ : anaerobic condition, $0 \% \mathrm{CaO}$; $\mathrm{ANC} 5 \mathrm{CaO}$ : anaerobic condition, $5 \% \mathrm{CaO}$. 
This leads to an increase in water-soluble compounds and enzyme-substrate interaction (Wang et al., 2012). Greater participation of fraction a $(\mathrm{p}<0.05)$ under anaerobiosis was observed for treated and untreated hulls compared to the aerobic condition (Table 3 ). The use of soluble components by microorganisms in the hulls under aerobiosis likely caused the reduction of this fraction (Table 2 ).

Chaudhry (2000) evaluated in situ degradability of wheat straw treated with $\mathrm{CaO}$ (160 $\mathrm{g} \mathrm{kg}^{-1}$ in the DM) in an anaerobic environment and found increased soluble fraction, recording 10.8 and $27.9 \%$ for untreated and treated straw, respectively. The same pattern was reported by Monção et al. (2014), who treated banana peels with $\mathrm{CaO}$ (40 $\mathrm{g} \mathrm{kg}^{-1}$ fresh matter) obtaining 46.26 and $41.65 \%$ in situ degradability for the treated and untreated peels respectively. The $\mathrm{CaO}$ increased fraction $\mathrm{b}$ (Table 3 ). When $\mathrm{CaO}$ was used (30 $\mathrm{g} \mathrm{kg}^{-1}$ fresh matter) for sugarcane hydrolysis, Romão et al. (2013) observed 11.4 percentage points increase in fraction $b$ in comparison with fresh sugarcane. Accordingly, $\mathrm{CaO}$ increases the digestible fractions when used for the treatment of fibrous roughages.

A high PD value was recorded under anaerobiosis (Table 3 ). The reaction temperature might have had a positive influence on this outcome, since $3 \mathrm{~h}$ after the hulls were treated with $\mathrm{CaO}$, higher temperatures were recorded $\left(43.37^{\circ} \mathrm{C}\right)$ compared with the aerobic environment $\left(37.52^{\circ} \mathrm{C}\right)$. This higher temperature may reflect a better environment within the closed container. Because heat from exothermal reaction of the chemical treatment is retained, these factors may interact with the substrate, therefore improving the results. Chaudhry (2000) treated wheat straw with $\mathrm{CaO}\left(160 \mathrm{~g} \mathrm{~kg}^{-1}\right.$ DM) under anaerobiosis, observing a $92.3 \% \mathrm{PD}$ of DM in the treated, and $54.1 \%$ in the untreated straw, which represents 38.2 percentage points increase in the treated material. In the present study, this increase in PD was 4.68 percentage points for the treated hulls under anaerobiosis compared with the untreated material in the same environment (Table 3). The difference in $\mathrm{PD}$ increase is probably due to the $\mathrm{CaO}$ dose used. Considering the dose of $160 \mathrm{~g} \mathrm{~kg}^{-1} \mathrm{DM}$ as high, Chaudhry (2000) suggested further studies for reducing the amount of $\mathrm{CaO}$ without affecting the alkali action on fiber components.

A similar response to that of PD was observed for ED at the different rates used (Table 3). The ED value (rates: 2 and 5\%/h) for hulls treated with $\mathrm{CaO}$ under anaerobiosis in this study was higher than the ED of corn silage reported by Cavalcante et al. (2012) at the same respective passage rates. This demonstrates the potential usage of this residue in diets for different animal categories.

Regarding estimated NDF parameters, the increase of fraction $b$ and reduction of fraction I when using $\mathrm{CaO}$ (Table 4) can be explained by the action of the alkaline agent in the cell wall components, reflecting in solubilization of part of the undegradable constituents (Balieiro Neto et al., 2007; Romão et al., 2013) thereby increasing fiber degradation (Chaudhry, 2000). As for the different environments, these fractions presented higher values in anaerobiosis. This effect may be due to the action of molds and yeasts, which grow rapidly in aerobiosis, consuming part of the nutrients present in the substrate (McDonald et al., 1991).

The use of $\mathrm{CaO}$ for the treatment of coffee hulls reduces the cell wall components and undegradable fiber fraction and increases PD and ED of DM. Anaerobiosis was the best environment for $\mathrm{CaO}$-treated hulls. Anaerobiosis also promotes improvements in untreated hulls. Further studies are needed to evaluate its effects on intake and productive performance of ruminants.

\section{Declarations}

\section{Acknowledgments}

We want to acknowledge the people at Fundação de Amparo à Pesquisa do Estado de Minas Gerais, FAPEMIG, Brazil, for their support during the study. 


\section{Funding}

This study was funded by Conselho Nacional de Desenvolvimento Científico e Tecnológico (CNPq), Coordenação de Aperfeiçoamento de Pessoal de Nível Superior (CAPES), Brazil.

\section{Conflicts of interest}

The authors declare they have no conflicts of interest with regard to the work presented in this report.

\section{Author contributions}

João P S Roseira performed the experiment, analyses and prepared the manuscript. Rasmo G. designed the experiment and contributed to the writing of the manuscript. Tâmara $\mathrm{C}$ da-Silveira assisted in chemical composition analyses. Cristina M Veloso contributed to the writing of the manuscript. Thiago $\mathrm{C}$ da-Silva performed the statistical analyses and contributed to the writing of the manuscript. Leandro D da-Silva assisted in degradability analyses and chemical composition. Everton $\mathrm{T}$ Ribeiro assisted in chemical composition analyses.

\section{References}

Balieiro Neto G, Siqueira GR, Reis RA, Nogueira JR, Roth MTP. Óxido de cálcio como aditivo na ensilagem de cana-de-açúcar. Rev Bras Zootec 2007; 36(5):1231-1239. DOI: https://dx.doi.org/10.1590/S1516$\underline{35982007000600003}$

Bruttel P, Schlink R. Water determination by Karl Fischer titration. $1^{\text {nd }}$ ed. Herisau (SWI): Metrohm; 2006.

Cavalcante DR, Perin FB, Benedetti E. Degradabilidade in situ da matéria seca de três forrageiras tropicais nas formas in natura e ensilada. ArqBrasMedVetZootec2012;64(1):163-168.DOI: https://dx.doi.org/10.1590/S0102$\underline{09352012000100023}$

Chaudhry AS. Rumen degradation in sacco in sheep of wheat straw treated with calcium oxide, sodium hydroxide and sodium hydroxide plus hydrogen peroxide. Anim Feed Sci and Technol 2000; 83(3):313-323. DOI: https://doi.org/10.1016/S0377-8401(99)00134-0

Detmann E, Souza MA, Valadares Filho SC, Queiroz AC, Berchielli TT, Saliba EOS, Cabral LS, Pina DS, Ladeira MM, Azevedo JAG. Métodos para análise de alimentos. $1^{\text {nd }}$ ed. Visconde do Rio Branco (MG): Suprema; 2012.

Figueiredo MP, Lopes IO, Sousa FG, Moreira GR, Sousa LF, Cruz PG, Ferreira JQ. Parâmetros cinéticos da degradação ruminal da casca de café (Coffea arabica, L.) tratada com hidróxido de sódio (NaOH). Cien Anim Bras 2008; 9(1):23-29.

Jackson MG. The alkali treatments of straws. J Agri Sci and Tech 1977; 2(2):105-130. DOI: https://doi.org/10.1016/0377-8401(77)90013-X

McDonald P, Henderson AR, Heron SJE. The biochemistry of silage. $2^{\text {nd }}$ ed. Aberystwyth (UK): Chalcombe Publications; 1991.

Monção FP, Reis ST, Rigueira JPS, Sales ECJ, Antunes APS, Oliveira ER, Carvalho ZG. Degradabilidade ruminal da matéria seca e da FND da casca de banana tratada com cal virgem. Rev Cien Agra 2014; 37(1):42-49. DOI: https://doi.org/10.19084/rca.16798

NRC- National Research Council. Nutrient Requirements of Dairy Cattle. $7^{\text {nd }}$ ed. Washington (USA): National Academy Press of Sciences; 2001.

Ørskov ER, McDonald I. The estimation of protein degradability in the rumen from incubation measurements weighted according to rate of passage. J of Agric Sci 1979; 92(2):499-503. DOI: https://doi.org/10.1017/S0021859600063048

Rocha FC, Garcia R, Freitas AWP, Souza AL, Gobbi KF, Valadares Filho SC, Tonucci, RG, Rocha, GC. Casca de café em dietas para vacas em lactação: consumo, digestibilidade, produção e composição do leite.RevBrasZootec2006;35(5):2163-2171.DOI: https://dx.doi.org/10.1590/S1516-35982006000700037

Romão CO, Carvalho GGP, Leite VM, Santos AS, Chagas DMT, Ribeiro OL, Pinto LFB, 
Oliveira RL. Fracionamento de carboidratos e degradabilidade ruminal da cana-de-açúcar tratada com óxido de cálcio. Arq Bras Med Vet Zootec 2013; 65(2):537-546. DOI: https://dx.doi.org/10.1590/S0102-09352013000200033

Russell JR, Loy DD, Anderson J, Cecava M. Potential of Chemically Treated Corn Stover and Modified Distiller Grains as a Partial Replacement for Corn Grain in Feedlot Diets; 2011. [access date: august 10, 2016]. URL: https:/lib.driastate.edu/ans air/vol657/iss1/10/

Sampaio CB, Detmann E, Paulino MF, Valadares Filho SC, Souza MA, Lazzarini I, Paulino PVR, Queiroz AC. Intake and digestibility in cattle fed low-quality tropical forage and supplemented with nitrogenous compounds. Trop Anim Health Prod 2010; 42(7):1471-1479. DOI: https://doi.org/10.1007/s11250-010-9581-7

SAS $^{\circledR}$, Statistical Analysis System. SAS/STAT User's Guide. Version 9.3. Cary (NC): SAS Institute Inc., 2011.

Sewell JR, Berger LL, Nash TG, Cecava MJ, Doane PH, Dunn JL, Duer MK, Pyatt NA. Nutrient digestion and performance by lambs and steers fed thermochemically treated crop residues. J Anim Sci 2009; 87(3):1024-1033. DOI: https://doi.org/10.2527/jas.2008-0974

Shreck AL. Use of alkaline treated crop residues as partial grain replacements for finishing cattle. Doctoral Thesis 2013; [access date: july 01, 2015]. URL: https://digitalcommons.unl.edu
Silva N, Junqueira VCA, Silveira NFA. Manual de métodos de análise microbiológica de alimentos. 1nd ed. São Paulo (SP): Varela; 1997.

Souza AL, Garcia R, Bernardino FS, Campos JMS, Valadares Filho SC, Cabral LS, Gobbi KF. Casca de café em dietas para novilhas leiteiras: consumo, digestibilidade e desempenho. Rev Bras Zootec 2006; 35(3):921-927. DOI: http://dx.doi.org/10.1590/S1516-35982006000300039

Valadares Filho SC, Machado PAS, Chizzotti ML, Amaral HF, Magalhães KA, Rocha Júnior, AR, Capelle ER. Tabela brasileira de composição de alimentos para bovinos. $3^{\text {nd }}$ ed. Viçosa (MG): Editora UFV; 2010.

Vargas E, Cabeza MT, Murillo B, Braham EJ, Bressani R. Effecto de altos niveles de pulpa de café deshidratada sobre el crescimento y adaptación de novillos jovenes. Arch Lat Amer Nutric 1982, 32(4):972-989.

Waldo DR, Smith LW, Cox LE. Model of cellulose disappearance from the rumen. J Dairy Sci 1972; 55(1):125-129. DOI: https://doi.org/10.3168/jds.S0022-302(72)85442-0

WangZ,RuyuL,MaritaJM,HatfieldDR,QuR,Cheng JJ. Sodium hydroxide pretreatment of genetically modified swichgrass for improved enzymatic release of sugars. Bio Tech 2012; 110(1):364-370. DOI: https://doi.org/10.1016/j.biortech.2012.01.097 